\title{
The effect on entrepreneurship student program on student's entrepreneurial behavior in Indonesia
}

\author{
Deden Dinar Iskandar ${ }^{a^{*}}$ and Imam Noor Said ${ }^{\mathrm{a}}$
}

${ }^{a}$ Department of Economics, Faculty of Economics and Bussiness, Diponegoro University, Indonesia

\begin{tabular}{l} 
C H R O N I C L E \\
\hline Article history: \\
Received: October 14, 2020 \\
Received in revised format: \\
November 112020 \\
Accepted: November 14, 2020 \\
Available online: \\
November 14, 2020 \\
\hline Keywords: \\
Entrepreneurial Behavior \\
Entrepreneurial Intention \\
Entrepreneurship Student Pro- \\
gram (ESP) \\
Theory of Planned Behavior \\
(TPB)
\end{tabular}

\section{A B S T R A C T}

\begin{abstract}
This study adopts the Theory of Planned Behavior (TPB) framework to examine the effect of the government-initiated Entrepreneurship Student Program (ESP) on the entrepreneurial intentions and behavior of students. In addition, the research also examines the market information adequacy and standard psychological components of TPB, namely attitude, subjective norms, and perceived behavioral control as predictor variables. Data are collected from 208 university students in Semarang, Indonesia, with the Partial Least Squares - Structural Equation Modeling (PLS-SEM) technique employed for analysis. The result shows that ESP and the adequacy of market information directly influence the entrepreneurial behavior of Indonesian students, while the influence of attitudes and perceived behavior control is mediated by entrepreneurial intention. In conclusion, this study implies that ESP can be considered effective in preparing and facilitating entrepreneurship among university students, therefore the government needs to consider increasing its availability to cover a larger number of universities in Indonesia.
\end{abstract}

(C) 2021 by the authors; licensee Growing Science, Canada

\section{Introduction}

Unemployment among university graduates has been identified as a serious problem in Indonesia, thereby leading to the initiation of the Student Entrepreneurship Program (ESP) by the Ministry of Education to facilitate, train and financially support them to run new business ventures. This program is in line with the growing recognition of entrepreneurship as an alternative to reduce the unemployment level in Indonesia. Nadim and Seymour (2008) define entrepreneurship as the phenomena associated with entrepreneurial activity, which is associated with the action of individuals actively seeking to generate economic values, through the creation, identification, and exploitation of new products, processes, or markets. The entrepreneurial activity includes a wide range of actions, from the business planning process to the implementation stage. The theory of Planned Behavior (TPB) framework has been used extensively in entrepreneurship studies to examine entrepreneurial behavior. Ajzen $(1991 ; 2001)$ states that behavior can be predicted by attitudes, perceived behavioral control, and subjective norms. Attitudes refer to the extent to which individuals have positive or negative personal judgments of certain behavior. Meanwhile, subjective norms are associated with significant social pressure from reference groups such as family, friends, and other important individuals that approve or disapprove of a person's behavior. Furthermore, perceived behavioral control is defined as an individual's beliefs on relative ease or difficulty in performing particular behavior. TPB is also defined as a direct antecedent of behavioral intention that mediates the effect of the three psychological predictors on behavior. The intention is related to the amount of energy, time, and resources that an individual is willing to put into performing a particular behavior. Entrepreneurial behavior is also influenced by the ease at which individuals secure necessary information in developing a business (Davidsson \& Honig, 2003). Hoang and Antoncic (2003) and Edelman and Yli-Renko (2010) state that adequate market information enhances the entrepreneur's ability to recognize and utilizes opportunities. It is also essential to understanding alternative opportunities and one of the conditions that must be met by entrepreneurs (Endres and Woods, 2006). According to Wang et al. (2019), information allows individuals to produce new competitive products efficiently by utilizing available resources. Therefore, based on the above background, this study aims to analyze the repercussion of ESP on student entrepreneurial behavior in Indonesia while controlling the effect of market information adequacy, within the framework of the Theory of Planned Behavior (TPB). The study is also expected to fill the gap in the effectiveness of ESP in * Corresponding author. Tel.: +62 2476486851 ; Fax.: +62 2476486852

E-mail address: deden dinar@live.undip.ac.id (D. D. Iskandar) 
fostering entrepreneurial intention and behavior among university students in the Indonesian context. Furthermore, it can provide insight into the effectiveness of ESP in Indonesia, and enrich the literature on similar programs by encouraging entrepreneurial behavior among students.

\section{Literature Review and Hypotheses Formulation}

\subsection{Theory of Planned Behavior}

The theory of Planned Behavior (TPB) formulated by Ajzen (1991, 2001) provides a coherent general framework for understanding individuals' entrepreneurial behavior (Kautonen et al., 2012). TPB stated that attitudes, perceived behavioral control, and subjective norms are the main determinants of behavior and the influence of these psychological factors can be mediated by intention, as well as the direct antecedent. Entrepreneurial behavior is the process of creating economic activities that involve the identification and exploitation of new processes, products, or markets (Nadim and Seymour, 2008). According to Thompson (2009) entrepreneurial intention is a conscious willingness to start a new business. Meanwhile, Krueger et al. (2000) stated that it can be used as a direct predictor of entrepreneurial behavior. Furthermore, Williams-Middleton (2010) reports that entrepreneurial intentions among college students had a significant influence on their behavior. Entrepreneurial attitude plays an important role in determining students' entrepreneurial intentions. Students with positive entrepreneurship attitudes tend to run their own businesses in future (Solesvik, 2013; Duong et al., 2020). Several previous studies have confirmed a significant relationship between subjective norm and intention to start a business (Koe et al., 2012; Uygun \& Kasimoglu, 2013; Solesvik, 2013; Duong et al., 2020). The result of these studies showed that the perceived approval of entrepreneurship from influential reference groups encourages individuals to undertake entrepreneurial activities. Furthermore, these existing studies also illustrated that perceptions of behavioral control are positively related to entrepreneurial intentions (Shook \& Bratianu, 2010; Ambad \& Damit, 2016; Solesvik, 2013; Duong et al., 2020). This is because individuals are more encouraged to assume entrepreneurial profession when they believe in their ability to complete the associated tasks.

H1: There is a significant influence of entrepreneurial intentions on student entrepreneurial behavior.

$\mathrm{H} 2 \mathrm{a}$ : There is a significant influence of attitude on students' entrepreneurial intentions.

$\mathrm{H} 2 \mathrm{~b}$ : There is a significant influence of attitude on students' entrepreneurial behavior.

H3a: There is a significant influence of subjective norms on students' entrepreneurial intentions.

$\mathrm{H} 3 \mathrm{~b}$ : There is a significant influence of subjective norms on students' entrepreneurial behavior.

H4a: There is a significant influence of perceived behavioral control on students' entrepreneurial intentions.

$\mathrm{H} 4 \mathrm{~b}$ : There is a significant influence of perceived behavioral control on students' entrepreneurial behavior.

\subsection{Entrepreneur Student Program (ESP)}

The government needs to encourage the development of new businesses by providing entrepreneurship education, training, and financial support. This is in accordance with the study carried out by Bridge and O'Neill (2012), and Ibrahim and Mas'ud (2016), which confirms a significant relationship between entrepreneurial skill and intention. A study carried out by Solesvik (2013) showed that participants of entrepreneurship programs in universities have the greater entrepreneurial motivation and a higher likelihood of becoming entrepreneurs. According to Lüthje \& Franke (2003), Gielnika et al. (2012), Sanchez (2013), and Fayolle and Gailly (2015), the presence of entrepreneurship programs stimulates the entrepreneurial intention of students and encourages them to realize their intention by developing a new business plan.

H5a: There is a significant influence of ESP on students' entrepreneurial intentions.

H5b: There is a significant influence of ESP on students' entrepreneurial behavior.

\subsection{Market Information Adequacy}

Market information is crucial for identifying and assessing entrepreneurial opportunities (Hoang and Antoncic, 2003; Gruber et al., 2008; Edelman and Yli-Renko, 2010). Garria and Konstantopoulosa (2013) state that those actively involved in searching for market information and continuously evaluating its potential demonstrate higher business performance. Furthermore, Lechner et al. (2006) find that accurate market information can augment the entrepreneurial behavior, while Fornoni et al. (2012) report that access to information can enhance entrepreneurial behavior.

H6a: There is a significant influence of market information adequacy on student entrepreneurial intentions.

H6b: There is a significant influence of market information adequacy on student entrepreneurial behavior.

Fig. 1 shows the structural model based on the formulated hypotheses. The model adopts the framework of TPB and extends it by incorporating ESP and market information adequacy. ESP and market information adequacy are modeled as predictors of entrepreneurial intention and behavior, along with psychological factors such as attitude, subjective norm, and perceived behavior control.

\subsection{Research Methods}

Data are collected from students of state universities in Semarang, Indonesia, using the survey and self-administered questionnaire methods. A total of 207 usable responses are obtained through an applied disproportionate stratified random sampling technique, by classifying the overall students into sub-groups in accordance with their participation ability in ESP. 
Several indicators measure the observed variables in the structural model as shown in Fig. 1. These indicators are formulated as assessable statements, which are evaluated using a Likert scale ranging from 1 ("strongly disagree") to 7 ("strongly agree").

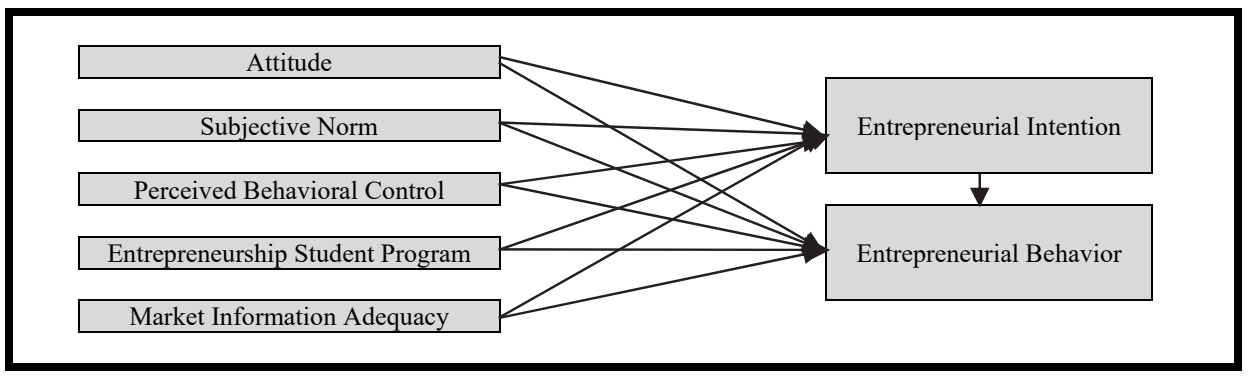

Fig. 1. Structural Model

The data are analyzed using the Partial Least Squares - Structural Equation Modeling (PLS-SEM) method, which is a statistical technique for determining, estimating, and evaluating linear relationships between a set of variables. The analysis consists of three main steps. The first step is associated with conducting reliability and validity tests to evaluate the strength of the relationship between variables (or constructs) with their respective indicators. These tests are important and used to confirm the validity and reliability of the chosen indicator used to measure the observed variables. The next step is assessing the model fit, to examine the extent to which variations of dependent variables can be explained by the predictor variables. The final step evaluates the pairwise causal relationship between variables in the model by conducting path analysis. This step includes estimating the path coefficients and testing its significance.

\section{Results and Discussion}

\subsection{Reliability and Validity}

This study firstly estimates composite reliability and convergent validity to verify the adequacy of indicators as the measures of inferred variables.

Table 1

The Results of Composite Reliability and Convergent Validity Tests

\begin{tabular}{|c|c|c|c|c|}
\hline Variables & Indicators & Factor Loading & AVE & CA \\
\hline \multicolumn{3}{|c|}{ Entrepreneurial Behavior } & 0.78 & 0.93 \\
\hline & I have spent my financial resource to start my business & 0.89 & & \\
\hline & I already started my own business & 0.89 & & \\
\hline & I have carefully made a financial calculation on the potential risks and profit of my business plan & 0.89 & & \\
\hline & I have spent considerable time to prepare my business plan & 0.87 & & \\
\hline & I am constantly looking for new business opportunities & 0.88 & & \\
\hline \multicolumn{3}{|c|}{ Entrepreneurial Intention } & 0.7 & 0.89 \\
\hline & I am motivated to grasp and attain what it takes to become an entrepreneur & 0.85 & & \\
\hline & I will be happy if I am able to run my own business & 0.81 & & \\
\hline & I regard entrepreneurship as my career path & 0.79 & & \\
\hline & I am willing to maximize my effort in running my own business & 0.89 & & \\
\hline & I am seriously considering running my own business & 0.85 & & \\
\hline \multirow[t]{6}{*}{ Attitude } & & & 0.74 & 0.91 \\
\hline & Entrepreneurship is likely to assist me with some economic benefits & 0.79 & & \\
\hline & An entrepreneurial career is appealing to me & 0.91 & & \\
\hline & Entrepreneurship gives me inner satisfaction & 0.92 & & \\
\hline & Entrepreneurship offers interesting and challenging activities & 0.89 & & \\
\hline & Entrepreneurial career deserves to be given high priority & 0.78 & & \\
\hline \multicolumn{3}{|c|}{ Subjective Norm } & 0.72 & 0.92 \\
\hline & My immediate family consider entrepreneurship a good career path & 0.78 & & \\
\hline & My immediate family approves of my entrepreneurship career path & 0.81 & & \\
\hline & My closest friends consider entrepreneurship a good career path & 0.87 & & \\
\hline & My closest friends will encourage me to become an entrepreneur & 0.88 & & \\
\hline & My closest community consider entrepreneurship a good career path & 0.86 & & \\
\hline & My closest community encouraged me to become an entrepreneur & 0.89 & & \\
\hline \multicolumn{3}{|c|}{ Perceived Behavioral Control } & 0.7 & 0.89 \\
\hline & I believe I have what it takes to run a business & 0.88 & & \\
\hline & I believe I have a good problem-solving capacity & 0.75 & & \\
\hline & I believe I have a good managerial skill & 0.85 & & \\
\hline & I have the courage to take risks amid uncertainty & 0.83 & & \\
\hline & I believe that I can identify and exploit business opportunities & 0.87 & & \\
\hline \multicolumn{3}{|c|}{ Entrepreneurial Student Program } & 0.94 & 0.93 \\
\hline & The information regarding ESP is easily accessible & 0.97 & & \\
\hline & I am registered as an ESP participant & 0.97 & & \\
\hline \multicolumn{3}{|c|}{ Market Information Adequacy } & 0.84 & 0.95 \\
\hline & I have adequate access to the necessary market information & 0.9 & & \\
\hline & I have adequate information regarding how the market works & 0.9 & & \\
\hline & I have adequate information regarding the supply line in the market & 0.92 & & \\
\hline & I have adequate information regarding market prices & 0.93 & & \\
\hline & I have adequate information regarding market demand & 0.94 & & \\
\hline
\end{tabular}


According to Hair et al. (2016), composite reliability illustrates the internal consistency of a set of indicators used to measure the same variable, while convergent validity refers to the extent to which that those indicators are interrelated. Composite reliability is measured by Cronbach's alpha and according to standard rule, it is statistically accepted when it is higher than 0.70. On the other hand, convergent validity is approximated by the Average Variance Extracted (AVE), with the threshold of acceptance at 0.50 . The detailed statistical results, along with the list of variables and their respective set of indicators, are shown in Table 1. The results showed that all inferred variables have adequate composite reliability and convergence validity. Furthermore, the Cronbach's alpha of all inferred variables exceeds the acceptable minimum value of 0.70 , and all values of AVE are higher than 0.50. Furthermore, the factor loading, which indicates the correlation between the inferred value of a variable and the observed indicator value, shows a considerably higher score, which implies the presence of stronger item reliability. In addition to composite reliability and convergent validity, this study also conducts a discriminant validity test to verify that indicators of different variables are not highly correlated. According to Hair et al. (2017), the AVE square root between indicators of the same variable needs to be higher than the correlation value between indicators of different variables. This is in accordance with the Fornell-Larcker criteria and statistical results shown in Table 2. The value of AVE square root (shown on diagonal) for each variable is clearly higher than the correlation values with different variables, thereby indicating that the required condition of discriminant validity has been met.

Table 2

The Results of Discriminant Validity Test

\begin{tabular}{|c|c|c|c|c|c|c|c|}
\hline Construct & INT & BHV & AT & SN & PBC & ESP & INF \\
\hline INT & 0.84 & & & & & & \\
\hline BHV & 0.48 & 0.88 & & & & & \\
\hline AT & 0.78 & 0.50 & 0.86 & & & & \\
\hline $\mathrm{SN}$ & 0.59 & 0.38 & 0.68 & 0.85 & & & \\
\hline PBC & 0.58 & 0.64 & 0.62 & 0.55 & 0.84 & & \\
\hline ESP & 0.30 & 0.55 & 0.35 & 0.35 & 0.48 & 0.97 & \\
\hline INF & 0.37 & 0.66 & 0.44 & 0.37 & 0.72 & 0.42 & 0.92 \\
\hline
\end{tabular}

INT: Entrepreneurial Intention; BHV: Entrepreneurial Behavior; AT: Attitude; SN: Subjective Norm; ESP: Entrepreneurship Student Program; INF: Market Information Adequacy.

All correlations are significant at a $1 \%$ significance level.

The construction of variables and their corresponding set of indicators have satisfied the required standard of composite reliability, as well as the convergence and discriminant validities. This indicates that the chosen indicators are valid and reliable in measuring the observed variables.

\subsection{Model Fit Assessment}

The model fit assessment evaluates the extent to which the structural model shown in Figure 1 fits the observations. The assessment indicates the process used by variations of dependent variables to explain the predictor. The statistical measures used in this study are Average R-squared (ARS), Adjusted Average R-squared (AARS), and Tenenhaus Goodness of Fit (GoF). The coefficients of ARS and AARS imply that the proportion of the variance independent variable that can be explained by predictor variables in the model. On the other hand, Tenenhaus GoF measures the explanatory power of the model, which is small, moderate, and large when the value is equal to or more than 0.1 , equal to or greater than 0.25 , and equal to or greater than 0.36 , respectively (Kock, 2017). The statistical results are shown in Table 3.

Table 3

Model Fit Assessment

\begin{tabular}{ccc}
\hline Index & Coefficient & P-value \\
\hline ARS & 0.61 & $<0.001$ \\
AARS & 0.60 & $<0.001$ \\
GoF & 0.69 & - \\
\hline
\end{tabular}

The GoF value of 0.69 is higher than the threshold in the category of large explanatory power with a value of 0.36 . Furthermore, the values of ARS and AARS also lie within an acceptable range at a 1\% level of significance. These results indicate that the structural model has an adequate fit model.

\subsection{Path Analysis}

The PLS-SEM enables the application of path analysis, a form of multiple regression statistical technique to examine the structural model by evaluating the pairwise relationships between a dependent variable and its predictor. The structural model in Figure 1 provides 11 paths or pairwise relationships, with each path associated with a specific hypothesis as formulated in section 2. The results of the path analysis estimation are shown in Table 4 . The path analysis has a 5\% significant level, which are shown by the path of entrepreneurial intention to behavior (INT $\rightarrow$ BHV), ESP to entrepreneurial behavior (ESP $\rightarrow$ BHV), market information adequacy to entrepreneurial behavior (INF $\rightarrow$ BHV), attitude to entrepreneurial intention (AT $\rightarrow$ INT), and perceived behavior control to entrepreneurial intention ( $\mathrm{PBC} \rightarrow \mathrm{INT}$ ). These findings confirm that entrepreneurial intention among students is closely related to a direct predictor of entrepreneurial behavior. ESP and market information adequacy tend to significantly affect the entrepreneurial behavior of students. On the other hand, attitude towards entrepreneurship and perceived behavioral control serve as significant predictors for students' entrepreneurial intentions. 
Table 4

Results of Path Analysis

\begin{tabular}{|c|c|c|c|c|}
\hline Hypotheses & Paths & Path Coefficients & P Values & Decisions \\
\hline $\mathrm{H} 1$ & $\mathrm{INT} \rightarrow \mathrm{BHV}$ & 0.16 & $<0.001$ & Accepted \\
\hline $\mathrm{H} 2 \mathrm{a}$ & $\mathrm{AT} \rightarrow \mathrm{INT}$ & 0.64 & $<0.001$ & Accepted \\
\hline $\mathrm{H} 2 \mathrm{~b}$ & $\mathrm{AT} \rightarrow \mathrm{BHV}$ & 0.09 & 0.14 & Not Accepted \\
\hline $\mathrm{H} 3 \mathrm{a}$ & $\mathrm{SN} \rightarrow \mathrm{INT}$ & 0.07 & 0.12 & Not Accepted \\
\hline $\mathrm{H} 3 \mathrm{~b}$ & $\mathrm{SN} \rightarrow \mathrm{BHV}$ & 0.09 & 0.06 & Not Accepted \\
\hline $\mathrm{H} 4 \mathrm{a}$ & $\mathrm{PBC} \rightarrow \mathrm{INT}$ & 0.21 & $<0.001$ & Accepted \\
\hline $\mathrm{H} 4 \mathrm{~b}$ & $\mathrm{PBC} \rightarrow \mathrm{BHV}$ & 0.14 & 0.08 & Not Accepted \\
\hline $\mathrm{H} 5 \mathrm{a}$ & $\mathrm{ESP} \rightarrow \mathrm{INT}$ & 0.01 & 0.38 & Not Accepted \\
\hline $\mathrm{H} 5 \mathrm{~b}$ & $\mathrm{ESP} \rightarrow \mathrm{BHV}$ & 0.30 & $<0.001$ & Accepted \\
\hline H6a & $\mathrm{INF} \rightarrow \mathrm{INT}$ & 0.08 & 0.08 & Not Accepted \\
\hline $\mathrm{H} 6 \mathrm{~b}$ & $\mathrm{INF} \rightarrow \mathrm{BHV}$ & 0.40 & $<0.001$ & Accepted \\
\hline
\end{tabular}

INT: Entrepreneurial Intention; BHV: Entrepreneurial Behavior; AT: Attitude; SN: Subjective Norm; ESP: Entrepreneurship Student Program; INF: Market Information Adequacy

The analysis fails to establish significant paths of attitude, subjective norm, and perceived behavior control to entrepreneurial behavior (AT $\rightarrow$ BHV; SN $\rightarrow$ BHV; PBC $\rightarrow$ BHV). The analysis is also unable to confirm the significant paths of subjective norm, ESP, and market information adequacy to entrepreneurial intention (SN $\rightarrow$ INT; ESP $\rightarrow$ INT; INF $\rightarrow$ INT). These findings imply that entrepreneurial behavior among university students cannot be attributed to attitude toward entrepreneurship, subjective norm, and perceived behavior control. Similarly, the entrepreneurial intention cannot be associated with subjective norms, ESP, and market information adequacy.

Those results indicate that psychological factors such as attitudes towards entrepreneurship and perceived behavior control do not directly influence entrepreneurial behavior, however, their effects are mediated by intention. A positive perspective toward entrepreneurship raises the interest of students in entrepreneurial activities. Similarly, when students show a convincing capability to complete entrepreneurial tasks, they are more eager to undertake entrepreneurial careers. On the other hand, this study is unable to determine a significant relationship between subjective norm with either entrepreneurial intention or behavior. The possible rationale for this phenomenon is that the culture of entrepreneurship is not properly embedded within Indonesian society. Furthermore, graduates are considered successful working in governmental agencies, state-owned companies, and big private companies are still perceived as indicators of successful university graduates.

This study confirms that entrepreneurial behavior is directly influenced by ESP and market information adequacy. The provision of entrepreneurship education and training as well as financial support included within the ESP program encourage students to develop entrepreneurial traits and activities. In addition to ESP, access to market information is also found to have a significant effect in determining entrepreneurial behavior. The process of starting a new business requires identifying available opportunities, therefore, having adequate market information tends to clarify ambiguous observations on business and ease the process of becoming entrepreneurs. On the other hand, there is no significant causal relationship between those factors and entrepreneurial intention. Further data analyze implies that the students without clear access to ESP and market information also demonstrate favorable intention toward entrepreneurship. Consequently, entrepreneurial intention cannot be attributed to ESP and market information adequacy.

\section{Conclusion}

This study aims to examine the effect of the Student Entrepreneurship Program (ESP) and market information on the entrepreneurial intentions and behavior of students, within the framework of the Theory of Planned Behavior (TPB). The study indicates that ESP and the adequacy of market information directly influence the entrepreneurial behavior of students in Indonesia, while the influence of attitudes on entrepreneurship and perceived behavior control is mediated by entrepreneurial intention. Furthermore, these findings suggest that the psychological factors such as attitude and perceived behavioral control provide the necessary conditions and more tangible factors such as ESP that are adequate for the provision of sufficient market information conditions needed for entrepreneurial behavior.

The results of this study imply that ESP is effective in preparing and facilitating entrepreneurship among students in Indonesia. In addition, the government can increase the use of ESP to cover a large number of universities. The adequacy of market information also significantly encourages the entrepreneurial behavior of students, therefore, the government needs to provide an accessible platform for broader dissemination of market information.

\section{References}

Ajzen, I (1991). The theory of planned behavior. Organizational Behavior and Human Decision Processes, 50(2), $179-211$. Ajzen, I (2001). Nature and operation of attitudes. Annual Review of Psychology, 52(1), 27-58.

Ambad, S.N.A., \& Damit, D.H.D.A. (2016). Determinants of entrepreneurial intention among undergraduate students in Malaysia, Procedia Economics and Finance, 37, 108-114.

Bridge, S., \& O'Neill, K. (2012). Understanding enterprise: Entrepreneurship and small business. Macmillan International Higher Education. 
Davidsson, P., \& Honig, B (2003). The role of social and human capital among nascent entrepreneurs. Journal of Business Venturing, 18(3), 301-331.

Duong, C., Nguyen, H., Ngo, T., Nguyen, V., \& Nguyen, T. (2020). The impact of individual and environmental characteristics on students' entrepreneurial intention. Management Science Letters, 10(3), 599-608.

Edelman, L., \& Yli-Renko, H (2010). The impact of environment and entrepreneurial perceptions on venture-creation efforts: Bridging the discovery and creation views of entrepreneurship. Entrepreneurship Theory and Practice, 34(5), 833-856.

Endres, A., \& Woods, C. (2006). Modern theories of entrepreneurial behavior: A comparison and appraisal. Small Business Economics, 26, 189-202.

Fayolle, A., \& Gailly, B. (2015). The Impact of Entrepreneurship Education on Entrepreneurial Attitudes and Intention: Hysteresis and Persistence. Journal of Organizational Change Management, 53(1), 75-93.

Fornoni, M., Arribas, I., \& Villa, J. (2012). An entrepreneur's social capital and performance: The role of access to information in the Argentinean case. Journal of Organizational Change Management, 25(5), 682-698.

Garria, M., \& Konstantopoulosa, N. (2013). Market information acquisition: A prerequisite for successful strategic entrepreneurship. Procedia - Social and Behavioral Sciences, 73, $643-651$.

Gielnika, M., Freseb, M., Bischoffa, K. M., \& Gordon ,M.F.O. (2016). Positive impact of entrepreneurship training on entrepreneurial behavior in a vocational training setting. Africa Journal of Management, 2(3), 330-348.

Gruber, M., MacMillan, I.C., \& Thompson, J.D. (2008). Look before you leap: Market opportunity identification in emerging technology firms. Management Science, 54 (9), 1652-1665.

Hair, J.F., Hult, G.T.M., Ringle, C., \& Sarstedt, M. (2016). A primer on partial least squares structural equation modeling (PLS-SEM). Sage Publications.

Ibrahim, N.A., \& Mas'ud, A. (2016). Moderating role of entrepreneurial orientation on the relationship between entrepreneurial skills, environmental factors and entrepreneurial intention: A PLS approach. Management Science Letters, $6(3), 225-236$.

Kautonen, T., Marco, G.V., \& Erno, T. (2012). Predicting entrepreneurial behaviour: A test of the theory of planned behaviour. Journal of Applied Economics, 45 (6), 697-707.

Koe, W. L., Sa'ari, J.R., Majid, I.A., \& Kamariah, I. (2012). Determinants of entrepreneurial intention among millennial generation. Procedia Social and Behavioral Sciences, 40, 197-208.

Krueger, N.F, Reilly, M.D., \& Carsrud, A.L. (2000). Competing models of entrepreneurial intentions. Journal of Business Venturing, 15(5-6), 411-432.

Lechner, C., Dowling, M., \& Welpe, I. (2006). Firm networks and firm development: The role of the relational mix. Journal of Business Venturing, 21(4), 514-540.

Lüthje, C., \& Franke, N. (2003). The 'making'of an entrepreneur: Testing a model of entrepreneurial intent among engineering students at MIT. R\&D Management, 33(2), 135-147.

Sanchez, J.C. (2013). The impact of an entrepreneurship education program on entrepreneurial competencies and intention. Journal of Small Business Management, 51(3), 447-465.

Shook, C.L., \& Bratianu, C. (2010). Entrepreneurial intent in a transitional economy: an application of the theory of planned behavior to Romanian students. International Entrepreneurship and Management Journal, 6(3), $231-247$.

Solesvik, M. Z. (2013). Entrepreneurial motivations and intentions: Investigating the role of education major. Education + Training, 55(3), 253-271.

Thompson, ER. (2009). Individual entrepreneurial intent: Construct clarification and development of an internationally reliable metric. Entrepreneurship Theory and Practice, 33(3), 669-694.

Uygun, R., \& Kasimoglu, M. (2013). The emergence of entrepreneurial intentions in indigenous entrepreneurs: The role of personal background on the antecedents of intentions. International Journal of Business and Management, 8(5), 24-40.

Wang, G., Li, L., \& Jiang, X. (2019). Entrepreneurial business ties and new venture growth: The mediating role of resource acquiring, bundling and leveraging. Sustainability, 11(1), 1-19.

Williams-Middleton, K. (2010). Developing entrepreneurial behavior. Facilitating nascent entrepreneurship at the university. Chalmer University of Technology.

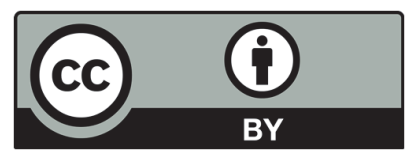

(C) 2021 by the authors; licensee Growing Science, Canada. This is an open access article distributed under the terms and conditions of the Creative Commons Attribution (CC-BY) license (http://creativecommons.org/licenses/by/4.0/). 